University of Nebraska - Lincoln

DigitalCommons@University of Nebraska - Lincoln

Faculty Papers and Publications in Animal

Science

Animal Science Department

2020

Bovine Respiratory Disease Influences on Nutrition and Nutrient

Metabolism

Clinton R. Krehbiel

University of Nebraska-Lincoln, clint.krehbiel@unl.edu

Follow this and additional works at: https://digitalcommons.unl.edu/animalscifacpub

Part of the Genetics and Genomics Commons, and the Meat Science Commons

Krehbiel, Clinton R., "Bovine Respiratory Disease Influences on Nutrition and Nutrient Metabolism" (2020). Faculty Papers and Publications in Animal Science. 1115.

https://digitalcommons.unl.edu/animalscifacpub/1115

This Article is brought to you for free and open access by the Animal Science Department at DigitalCommons@University of Nebraska - Lincoln. It has been accepted for inclusion in Faculty Papers and Publications in Animal Science by an authorized administrator of DigitalCommons@University of Nebraska Lincoln. 


\title{
Bovine Respiratory Disease Influences on Nutrition and Nutrient Metabolism
}

\author{
Clinton R. Krehbiel
}

Department of Animal Science, University of Nebraska-Lincoln, C203 Animal Science Complex, 3940 Fair Street PO Box 830908, Lincoln, NE 68583-0908,

USA; email ckrehbiel2@unl.edu

\section{Key points}

- Inflammation caused by bovine respiratory disease (BRD) continues to be one of the greatest challenges facing beef cattle producers and feedlot managers.

- BRD results in decreased intake, daily gain, and feed efficiency in feedlot calves, decreasing growth rate and increasing required days on feed.

- Morbidity caused by BRD has been associated with decreased hot carcass weight and poor carcass characteristics.

- Acute phase protein production in the liver, initiated by proinflammatory cytokines, may shift the priority for amino acid and energy use by the host animal during periods of sickness.

- Nutrient requirements for stressed calves seem to be the same as for nonstressed calves; however, nutrients should be concentrated early in the receiving period to account for low dry matter intake.

Keywords: Acute phase response, Feedlot cattle, Inflammation, Nutrient requirements, Stress

Published in Veterinary Clinics: Food Animal Practice 36 (2020) 361-373

DOI: 10.1016/j.cvfa.2020.03.010

Copyright (c) 2020 Elsevier Inc. Used by permission. 


\section{Introduction}

The bovine respiratory disease (BRD) complex is the major cause of morbidity and mortality in growing and finishing cattle. BRD is a multifaceted disease generally caused by a combination of stress and viral and bacterial infections. The primary stressors encountered by calves during the marketing process include removal from dam, feed and water deprivation, exposure to new animals and pathogens, and castration/dehorning. ${ }^{1}$ These stressors can weaken the immune system and allow infection to occur. The major viruses normally involved in BRD are infectious bovine rhinotracheitis virus, bovine viral diarrhea viruses (BVDVs), parainfluenza type-3 virus, and/or bovine respiratory syncytial virus (BRSV). Viruses can weaken the immune defenses and allow secondary infection by bacteria to occur in the lungs of the compromised calf. Bacteria most commonly isolated from lungs of calves infected with BRD are Mannheimia haemolytica, Pasteurella multocida, Histophilus somni, and Mycoplasma bovis. Bovine viral diarrhea virus has been isolated alone or in combination with other viral and bacterial pathogens in animals diagnosed with BRD. Cattle persistently infected with BVDV have been reported as the main source of disease transmission in feedlot settings, ${ }^{2}$ and the presence of an animal persistently infected with BVDV in a feedlot pen has been reported to increase the risk of antimicrobial treatment of BRD by $43 \%$ compared with nonexposed cattle. ${ }^{3}$

The impact of BRD on nutrient requirements has been studied and debated for many years. Because nutrition and stress are interrelated, it is important to consider how both can be managed to minimize the potential impact of BRD on animal health and performance. Stress can produce or aggravate nutritional deficiencies, and nutritional deficiencies can produce a stress response. Because stress can alter the steady state of the body and challenge physiologic adaptive processes ${ }^{4,5}$ management of stress in cattle should involve removal of the cause of stress, and management of the physiologic changes observed in animals caused by stress. Theoretically, meeting nutrient requirements of calves should help them overcome the physiologic changes associated with stress. In contrast, it has become clear through several experiments that, after calves get sick, 
the economics of all subsequent segments of the beef industry are negatively affected. . $^{6-12}$ These experiments have compared the economics and performance of cattle that become sick and require treatment with those that remain healthy throughout the growing and finishing phase. Results consistently show that, if an animal gets sick, the combination of mortality, medical costs, decreased performance, and poorer carcass quality results in decreased net returns for morbid calves compared with calves that remain healthy throughout the growing/finishing phase of production.

Calves of known origin and background or preconditioned calves, where health management practices (e.g., dehorning, castration, vaccination, and weaning at least 30 days before transport) are known, have decreased risk for BRD compared with market-sourced calves with unknown history. Step and colleagues ${ }^{13}$ reported that newly weaned calves shipped directly from a ranch to a receiving facility and maintained separately showed less morbidity, lower health cost, and greater daily gains than calves purchased from multiple sources and commingled before shipment. Health costs and daily gains from commingled groups made up of freshly weaned calves shipped immediately from the ranch and market-sourced calves were not different from market-sourced calves that were not commingled. However, compared with ranch calves weaned and then immediately shipped or market-sourced calves, this experiment indicated that weaning calves for 45 days on the ranch of origin before shipping resulted in less morbidity and lower medicine costs when they arrived the receiving facility whether they were maintained separately or commingled with market-sourced calves. ${ }^{13}$

Preweaning interventions can also provide potential benefits. Creep feeding or limit feeding calves for 6 to 8 weeks before weaning seems to have economic benefits compared with a program in which calves are weaned and fed ad libitum for 4 weeks before marketing. ${ }^{14}$ Whether ranch sourced, preconditioned, or market-sourced calves are purchased, the objectives of the receiving health and nutrition program are to assist the calf in recovering from stress, optimize the immune response, and shorten the time to begin productive weight gain during the next phase of production. 


\section{Stress effects on nutrient metabolism}

Inflammation resulting from BRD or other diseases or injury serves to protect tissues, which maintains homeostasis and supports animal survival. However, sustained stimulation of the inflammatory response impairs normal growth and development, and may prevent an animal from attaining its full genetic potential for growth and carcass merit. Direct interactions between proinflammatory molecules and muscle, fat, mammary, and intestinal epithelial cells result in modifications of their metabolic and anabolic functions. When viral and bacterial pathogens, trauma, or stress overcome host defenses, the innate immune system initiates a rapid and systemic acute phase response (APR). Molecules from pathogens are detected by toll-like receptors, which stimulate the production of proinflammatory cytokines (e.g., tumor-necrosis factor-alpha, interleukin [IL]-1a, IL-1b, IL-6) and leads to an APR, fever, anorexia, muscle catabolism, coagulation, increased glucocorticoid hormone levels, changes in liver protein synthesis, and leukocytosis. ${ }^{15-17}$ Although such a response is invaluable to the health of the animal, it can have consequences for growth and other physiologic outcomes. A sustained systemic immune response can increase risk of sepsis, organ failure, and mortality. ${ }^{18,19}$

The APR provides an early nonspecific defense against pathogen challenge through a process that involves metabolic changes. ${ }^{20} \mathrm{As}$ part of the early defense mechanism, acute phase proteins (APP) are produced in the liver. ${ }^{21,22}$ APP production is initiated by proinflammatory cytokines. ${ }^{23}$ In addition, Cooke and Bohnert ${ }^{24}$ showed that increased circulating levels of cortisol resulted in increased levels of IL-6 and haptoglobin $(\mathrm{Hp})$, indicating that the APR can be activated by systemic increases in the stress marker cortisol. As a component of the APR, the liver alters metabolism to increase or decrease the production of APP. The increased demand for amino acid (AA) for production of APP by the liver is likely supplied by muscle protein catabolism and subsequent AA uptake by the liver. ${ }^{25}$ In addition, the liver provides energy substrates to the peripheral tissues in exchange for the AA substrates needed for protein synthesis. Whether the negative impact of BRD on growth could be prevented by supplying the proper array of AA and energy substrate to meet demands of the liver during inflammation needs further study. 
It is unclear how or whether an APR can negatively affect long-term growth and carcass characteristics. Berry and colleagues ${ }^{26}$ observed sustained increased $\mathrm{Hp}$ levels in calves requiring multiple treatments for BRD. Hp levels remained high for 28 days, indicating that calves receiving multiple treatments experience a sustained APR. In contrast, Burciaga-Robles and colleagues ${ }^{27}$ showed a short APR in a BRD challenge model. There is limited information regarding APP levels or the APR throughout for multiple treatments for naturally acquired $B R D$ and subsequent harvest. Because the APR can be stimulated by cortisol, ${ }^{24}$ it might be difficult to distinguish between increased levels of APP in response to animal handling or other stressors versus increased levels caused by illness. It is clear that increased APP levels are associated with decreased daily gain, ${ }^{28,29}$ and the APR and inflammatory responses, regardless of initiator, alter metabolic function in a variety of tissues.

Cattle are different from other species in that $\mathrm{Hp}$ and serum amyloid A (SAA) are the major APPs with levels that are observed to increase during infections. ${ }^{16,17}$ Changes in $\mathrm{Hp}$ levels have been observed caused by several bacterial and viral infections, including $M$ haemolytica and $P$ multocida, BVDV, and BRSV, all of which are common BRD pathogens..$^{17,20}$ In addition, SAA is a second definitive positive APP in cattle and levels have been shown to be increased during acute inflammation and BRD. 30,31 The significant changes in protein synthesis that occur in the liver likely modify AA requirements for the host animal. Waggoner and colleagues ${ }^{32}$ challenged beef steers with endotoxin, and plasma concentrations of isoleucine and leucine decreased 4 hours after infusion with lipopolysaccharide compared with unchallenged controls. Reeds and colleagues ${ }^{33}$ $\alpha$-glycerophosphate, $\alpha_{1}$-antitrypsin, SAA, and $\mathrm{Hp}$ ) and muscle protein and calculated that the demand for the aromatic AAs (i.e., phenylalanine, tyrosine, and tryptophan) would lead to more than twice the amount of AA in skeletal muscle needed to be mobilized to accommodate APP synthesis. This need for specific AAs indicates the detriment that an APR may have on muscle in beef cattle with BRD. Future research is needed to describe changes in liver and peripheral tissue metabolism in calves affected by BRD and the immunologic signals that are responsible for long-term growth impairment and potential changes in carcass composition. 


\section{Influence of nutrition on bovine respiratory disease}

A consistent response in stressed calves that show clinical signs of BRD is a decrease in dry matter intake (DMI). In addition, technologies that allow the determination of feeding behavior have shown that changes in patterns of feeding behavior and DMI are good predictors of calves that will be treated for BRD. 34,35 Feed intake by lightweight stressed calves averages only $1.5 \%$ of body weight (BW) during the first 2 weeks after arrival to a feeding facility ${ }^{36,37}$ (Table 1). In a summary of 18 experiments involving transit-stressed calves, $83.4 \%$ of morbid calves and $94.6 \%$ of healthy calves had consumed any feed by day 7 following arrival to the feedlot. ${ }^{36}$ In addition, measured DMI of morbid calves was $58 \%, 68 \%$, and $88 \%$ of healthy calves across days 1 to 7 , 1 to 14 , and 1 to 56 , respectively. Similarly, Sowell and colleagues 38 observed that $94 \%$ of calves identified as healthy and $87 \%$ of morbid calves visited the feed bunk on the day of arrival, and $100 \%$ of healthy calves and only $91 \%$ of morbid calves had visited the bunk by day 3 . In a second experiment, ${ }^{38}$ only $13 \%$ and $10 \%$ of healthy and morbid calves, respectively, visited the feed bunk on day 1 . All healthy calves had visited the bunk by day 4 , but only $76 \%$ of morbid calves were observed at the feed bunk. In both experiments, healthy calves had more overall feeding events per day and spent more time at the bunk daily than morbid animals, both during the first 4 days and throughout the 32-day experiment. Total calves identified as sick were $52 \%$ in experiment 1 and $82 \%$ in experiment $2,{ }^{38}$ which likely explains the greater variation in feeding behavior. In both experiments, $80 \%$ of morbid calves were identified within 10 days of arrival.

It is apparent that newly received, highly stressed calves consume less feed than healthy calves exposed to fewer stress factors. As such,

Table 1. Dry matter intake (percentage of body weight) of newly arrived calves transported from Tennessee to Texas

\begin{tabular}{ccc} 
Days After Arrival & Healthy Calves & Sick Calves \\
\hline $0-7$ & 1.6 & 0.9 \\
$8-14$ & 1.9 & 1.4 \\
$15-28$ & 2.7 & 1.8 \\
$28-56$ & 3.0 & 2.7 \\
\hline
\end{tabular}


current recommendations are for nutritionists to increase the density of nutrients in diets of stressed calves so that animal requirements for nutrients are met even when intake is low. ${ }^{39}$ In commercial settings, it is unclear whether disease causes decreased intake or decreased intake is responsible for disease incidence. After recovery, DMI may remain low or be similar compared with nontreated animals. However, there is evidence that, on recovery, morbid animals experience compensatory gain compared with nontreated animals. This compensation may be caused by recovering gastrointestinal fill or reduced competition for nutrients when cattle are moved from preconditioning pens to pasture ${ }^{40}$ or are adapted to a finishing diet. ${ }^{41}$ McBeth and colleagues ${ }^{41}$ segregated heifers by the number of BRD treatments ( 0 or 1 ) administered during a 42-day preconditioning period and observed subsequent finishing performance. At the beginning of the finishing phase, no difference in BW between healthy and morbid steers existed. However, daily gain was increased $14.4 \%$ and $5.8 \%$ for treated heifers during day 0 to 28 and day 0 to 112 , respectively. Although DMI was not different at any time during the 140-day finishing period, the increase in daily gain resulted in treated heifers being more efficient during the first 28 days on feed. An experiment by Holland and colleagues ${ }^{42}$ showed that receivingphase and overall (arrival to end) daily gain were 59\% and $8.7 \%$ lower, respectively, for heifers treated 3 times for BRD compared with heifers that remained healthy throughout the feeding period. After the low growing phase gain by morbid animals, a compensatory response occurred in those animals, such that overall finishingphase daily gain was similar across BRD treatment categories, and feed efficiency was improved. Therefore, segregation according to previous number of BRD treatments during finishing may result in a compensatory response in daily gain and improved feed efficiency for treated animals. Similar results were observed by Wilson and colleagues. ${ }^{43}$ Although increased days on feed may be required to reach similar final BW and carcass characteristics, a restart program may be a viable alternative to realizing or railing animals treated multiple times for BRD. 


\section{Energy concentration and source}

Energy deficiency in cattle can severely depress the immune system ${ }^{44}$; however, excess dietary energy can also have detrimental effects. Feedlot studies suggest that the incidence of BRD in markettransport stressed calves is increased when the diet contains more than $60 \%$ concentrate. Although it is unlikely that the energy concentration of the diet is excessive in most receiving diets, it is possible that an energy deficit could occur because of poor forage quality and/or an inadequate supply of forage. Lofgreen ${ }^{45,46}$ reported that calves fed low-quality hay diets on arrival were not able to compensate for their lost early weight gain later in the feeding period.

A series of experiments with market-stressed calves was conducted to determine optimal dietary energy concentrations of receiving diets. ${ }^{4}$ In experiment 1 , diets with concentrations of $0.84,1.01$, and 1.10 $\mathrm{Mcal} / \mathrm{kg}$ of net energy for gain $\left(\mathrm{NE}_{\mathrm{g}}\right.$ ) (dry matter [DM] basis) were fed for 29 days followed by all treatment groups being fed the 1.01 $\mathrm{Mcal} / \mathrm{kg}$ of $\mathrm{NE}_{\mathrm{g}}$ diet for an additional 34 days. Calves received on the intermediate-energy and high-energy dietary treatments consumed more feed and gained more weight during the 29-day receiving period, with the calves consuming $1.10 \mathrm{Mcal} / \mathrm{kg}$ of $\mathrm{NE}_{\mathrm{g}}$ gaining more than the intermediate-energy treatment group at similar DMI. Calves on the high-energy and low-energy diets had lower morbidity rates than calves on the intermediate-energy treatment. Given the outcome of this study, Lofgreen and colleagues ${ }^{47}$ replaced the $0.84 \mathrm{Mcal} / \mathrm{kg}$ of $\mathrm{NE}_{\mathrm{g}}$ diet with a $1.19 \mathrm{Mcal} / \mathrm{kg} \mathrm{NE}$ diet to determine whether gain would increase further with increased dietary energy concentration. Intake decreased when the higher-energy diet was added and daily gain was not increased. In contrast with the previous study, calves on the $1.10 \mathrm{Mcal} / \mathrm{kg}$ of $\mathrm{NE}_{\mathrm{g}}$ diet consumed more feed than calves on the $1.01 \mathrm{Mcal} / \mathrm{kg}$ of $\mathrm{NE}_{\mathrm{g}}$ diet. Morbidity tended to increase with increasing energy concentration.

Fluharty and Loerch ${ }^{48}$ fed corn silage-based diets with 1.15, $1.21,1.25$, or $1.30 \mathrm{Mcal} / \mathrm{kg}$ of $\mathrm{NE}_{\mathrm{g}}$ to individually housed steers in a 28-day receiving study. There was a linear increase in DMI with increasing dietary energy concentration but there was no difference in daily gain, feed efficiency, or health status for the 28-day 
period. Similarly, DMI was improved and daily gain was not different between high-energy (1.17 Mcal/kg NE ) and low-energy (1.01 $\mathrm{Mcal} / \mathrm{kg} \mathrm{NE}_{\mathrm{g}}$ ) diets in a 28-day preconditioning study conducted by Pritchard and Mendez..$^{49}$ Berry and colleagues ${ }^{50}$ attempted to sort out the confounding effects of roughage and energy concentrations by feeding high-starch and low-starch concentrations within each of 2 dietary roughage concentrations. Energy concentration did not influence performance or overall morbidity, but morbid calves fed diets with the greater concentration had less shedding of $P$ multocida and $\mathrm{H}$ somni than those fed the lower-energy diets. Dietary roughage concentration varied over a narrow range of 35\% to $45 \%$ in the Berry and colleagues ${ }^{50}$ study, and therefore comparison with results from experiments with greater variation in roughage/energy concentration is difficult. Rivera and colleagues ${ }^{51}$ analyzed data to evaluate relationships between BRD and dietary roughage concentration in lightweight, stressed cattle. Diets ranged from all-hay to 75\% concentrate. Morbidity (i.e., percentage of calves treated for BRD using visual observation and rectal temperature) decreased as dietary roughage concentration increased [morbidity, \% $=49.59$ ( 0.0675 roughage, \%); $P 5$.003]. Average daily gain and DMI were decreased by increasing the dietary roughage concentration. In addition, economic analysis indicated that the slightly lesser morbidity noted with greater roughage concentrations would not offset the loss in profit resulting from decreased average daily gain. Rivera and colleagues ${ }^{51}$ concluded that milled diets with greater levels of concentrate would provide the optimal receiving diet for lightweight, highly stressed, newly received cattle, with limited effects on BRD. Grain type used in receiving diets does not seem to affect calf health or performance. ${ }^{39}$ Spore and colleagues ${ }^{52}$ reported that limit feeding high-energy rations based on low-starch corn by-products such as Sweet Bran (Cargill Corn Milling, Blair, NE) resulted in greater feed efficiency without affecting health of newly received, stressed cattle. Limit feeding a high-energy diet (1.32 Mcal of net energy [NE] $/ \mathrm{kg}$ of DM) containing $40 \%$ Sweet Bran during the receiving and growing phase improved feed efficiency by $22 \%$ compared with a low-energy diet (0.99 Mcal of NE/kg of DM) fed ad libitum. 


\section{Protein concentration and source}

Dietary protein requirements for beef cattle can be calculated using the National Academies of Sciences, Engineering, and Medicine $(\mathrm{NASEM})^{39}$ metabolizable protein model, which integrates BW and energy intake. Energy intake is the first-limiting nutrient involved with weight gain; therefore, protein deposited in gain largely depends on energy intake. ${ }^{53}$ Because newly received stressed calves often have very low intakes during the first few days, protein requirements might be low. Requirements would then increase as energy intake increases.

Effects of various protein levels and sources for newly received calves have been characterized. Galyean and colleagues ${ }^{54}$ fed 3 levels (12\%, $14 \%$, or $16 \%$ ) of supplemental crude protein (CP) from soybean meal to 120 calves (185 kg) in a 42-day receiving experiment. Daily gain increased and DMI tended to increase linearly with increasing CP concentration. Morbidity was higher for calves fed the highprotein diet compared with the 14\% CP diet. Fluharty and Loerch ${ }^{55}$ conducted a series of experiments to access protein requirements of newly arrived cattle. In experiment 1, newly weaned Simmental $x$ re fed increasing CP concentrations (12\%, 14\%, 16\%, or $18 \%$ ) from spray-dried blood meal or soybean meal. Feed efficiency improved linearly with increasing CP concentration for the first 7 days and for the entire 42-day feeding period. Daily gain increased linearly with increasing CP concentration during the first week after arrival. For the entire receiving period, calves fed the blood meal diets had a $7.4 \%$ increase in gain compared with calves fed the soybean meal diets. Similar to data reported by Galyean and colleagues, ${ }^{54}$ morbidity also increased linearly with increasing CP concentration, with cattle on the $12 \%, 14 \%, 16 \%$, and $18 \%$ CP diets experiencing 38\%, 50\%, 45\%, and $68 \%$ morbidity, respectively. A second experiment was conducted in which 246-kg Simmental Angus steers were fed 11\%, 14\%, 17\%, 20\%, $23 \%$, or $26 \%$ CP diets with protein supplied by spray-dried blood meal or soybean meal. ${ }^{55} \mathrm{DMI}$ was not affected by CP concentration. Daily gain and feed efficiency both responded quadratically, with the $20 \%$ CP diet yielding the greatest performance. There were no differences in health status between treatment groups. In a summary of several experiments, Galyean and colleagues ${ }^{56}$ noted that, as the protein concentration in receiving diets increased up to approximately 
$20 \%$ of DM, animal performance improved, but the incidence of BRD increased slightly. Cole ${ }^{14,57}$ suggested that a CP concentration of approximately $14.5 \%$ is optimal for newly received calves and would meet their protein requirements.

Pritchard and Bogg $5^{58}$ indicated that dried distiller's grains could effectively replace soybean meal as a protein supplement for incoming feedlot cattle. Morbidity rates in their study were very low $(<3 \%)$. Van Koevering and colleagues ${ }^{59}$ reported that replacing soybean meal with dried distiller's grains in a receiving supplement decreased performance but did not affect the incidence or severity of BRD.

In general, young calves have a limited capacity to use dietary urea. The NASEM ${ }^{39}$ suggests that intakes of $30 \mathrm{~g} / \mathrm{d}$ can be tolerated by stressed calves during the first 2 weeks of feeding. The use of ingredients high in ruminally undegraded protein (RUP) has been beneficial in some studies with calves on forage-based diets. It seems that RUP concentrations of $5.4 \%$ of dietary DM are generally adequate for stressed calves. ${ }^{39}$

\section{Minerals}

Because of low feed intakes, the concentrations of most minerals need to be increased in receiving diets. However, with the possible exception of $\mathrm{K}$, the mineral requirements (i.e., grams per day) of stressed calves do not seem to be increased. ${ }^{56}$

$\mathrm{Cu}, \mathrm{Zn}$, and Se have been shown to be essential for optimal immune function. Although several studies have reported a beneficial effect of supplemental $\mathrm{Cu}, \mathrm{Se}$, and $\mathrm{Zn}$ on some indicators of immune function, data have been inconsistent, and few studies have shown a positive effect on animal health or performance when the control diet was not deficient in these minerals. In general, beneficial effects of supplementing these trace minerals on immunity or the incidence of BRD in beef calves would most likely occur in animals with marginal or deficient mineral status. Because the mineral status of calves is rarely known, it is advantageous to supplement with these minerals, especially because most forages are marginal or deficient in at least 1 of these minerals or contain increased concentrations of antagonists, such as Mo and S. However, feeding excessive quantities of the trace 
minerals may not be helpful and is potentially harmful. A good rule of thumb is to provide $50 \%$ or more of mineral requirements in the daily supplement.

Although some studies have reported improved immune responses when calves were supplemented with organic forms of $\mathrm{Cu}, \mathrm{Zn}$, Se, or $\mathrm{Mn}$ (proteinates, AA complexes, and so forth), other studies have reported no effect. ${ }^{1,56}$ Garcia and colleagues ${ }^{60}$ reported that varying level and source of trace minerals did not affect growth performance or morbidity in newly received cattle, and Ryan and colleagues ${ }^{61}$ reported that source of $\mathrm{Cu}, \mathrm{Zn}$, and $\mathrm{Mn}$ had no effect on growth performance, morbidity, average antibiotic cost, plasma $\mathrm{Cu}$ and $\mathrm{Zn}$ concentrations, or antibody titer response to bovine viral diarrhea virus vaccination in shipping-stressed cattle over a 42-day to 45-day backgrounding phase. Supplying minerals in an AA-chelated form reduced the number of treatments required for morbid calves to recover from $B R D$ compared with a complex mineral form, although morbidity and mortality did not differ. ${ }^{62}$ In addition, an injectable trace mineral did not improve performance or morbidity when the incidence was low. ${ }^{63}$

The NASEM ${ }^{39}$ noted that results of recent experiments indicate a need for supplemental $\mathrm{Cr}$ in some situations. Reports by Chang and Mowat ${ }^{64}$ and Moonsie-Shageer and Mowat ${ }^{65}$ indicated that BW gain by feeder calves was increased by supplements of 0.2 to $1.0 \mathrm{mg}$ of $\mathrm{Cr}$ per kilogram of diet. The effect on morbidity was inconsistent. Bernhard and colleagues ${ }^{66}$ fed $221-\mathrm{kg}$ steers $0,0.1,0.2$, or $0.3 \mathrm{mg} / \mathrm{kg}$ of $\mathrm{Cr}$ (DM basis) from $\mathrm{Cr}$-propionate. $\mathrm{Cr}$-supplemented steers had improvements in DMI, feed efficiency, and daily gain within the first 28 days of the experiment, when cattle would have been under nutritional and physiologic stress. Through the remainder of the experiment, $\mathrm{Cr}-$ supplemented steers maintained these advantages.

\section{Vitamins}

Experiments with B-vitamin supplementation to newly weaned/ received cattle have resulted in variable responses, with decreased morbidity and increased performance in some studies and little or no response in others. ${ }^{14}$ In a review of several experiments, Cole ${ }^{14}$ noted a $3 \%$ decrease in BRD morbidity, a $4.2 \%$ increase in BW gain, and a $5.1 \%$ improvement in feed efficiency with supplemental B vitamins. 
Supplemental vitamin $\mathrm{E}$ in receiving diets seems to be beneficial for decreasing morbidity and improving performance. Several studies with feedlot diets suggest that feeding vitamin $E$ in excess of requirements may be beneficial to animal health. In general, results have been better when vitamin $E$ was fed than when it was injected. ${ }^{14,57}$ In a summary of results of cattle feedlot receiving studies, Elam ${ }^{67}$ noted that, as vitamin E supplementation increased from 0 to $2000 \mathrm{IU} / \mathrm{d}$, BRD decreased $0.35 \%$ for every $100-I U$ increase in vitamin $E$ intake. Results with supplementation of other fat-soluble vitamins have been inconsistent. ${ }^{14}$

Duff and Galyean ${ }^{1}$ concluded that, with the possible exception of $K$, the stressors of weaning, marketing, transport, and disease do not seem to increase total nutrient requirements of calves. However, because of low feed intakes, the concentrations of nutrients in the diet need to be increased to meet the nutrient requirements of the animals (Table 2). ${ }^{14,39,57}$

Table 2. Recommended nutrient concentrations in diets for stressed calves (dry matter basis)

\begin{tabular}{lll} 
Nutrient & Concentration & Comments \\
\hline Dry Matter (\%) & $80-85$ & Limit extreme high-moisture feeds \\
$\mathrm{NE}_{\mathrm{m}}(\mathrm{Mcal} / \mathrm{kg})$ & $1.3-1.6$ & Higher first 7-14 d \\
$\mathrm{NE}_{\mathrm{g}}(\mathrm{Mcal} / \mathrm{kg})$ & $0.8-0.9$ & Higher first 7-14 d \\
$\mathrm{CP}(\%)$ & $12.5-14.5$ & Limit urea to $<30 \mathrm{~g} / \mathrm{d}$ \\
$\mathrm{Ca}(\%)$ & $0.6-0.8$ & - \\
$\mathrm{P}(\%)$ & $0.4-0.5$ & - \\
$\mathrm{K}(\%)$ & $1.2-1.4$ & Avoid high Cl levels \\
$\mathrm{Na}(\%)$ & $0.2-0.3$ & Check water \\
$\mathrm{Mg}(\%)$ & $0.2-0.3$ & - \\
$\mathrm{S}(\%)$ & $0.15-0.25$ & Check water \\
$\mathrm{Mn}(\mathrm{ppm})$ & $40-70$ & - \\
$\mathrm{Co}(\mathrm{ppm})$ & $0.1-0.2$ & - \\
$\mathrm{Cu}(\mathrm{ppm})$ & $10-15$ & Higher if high S or Mo \\
Fe (ppm) & $100-200$ & - \\
Zinc (ppm) & $75-100$ & - \\
Se (ppm) & $0.1-0.2$ & - \\
Vitamin E (IU/d) & $400-500$ & Concentrate if pelleted \\
\hline
\end{tabular}




\section{Summary}

Nutritional management of newly received calves is key to recovery from stressors associated with weaning and marketing. Because of low initial intakes, nutrient deficiencies are difficult to meet and may limit the recovery process. More nutrient-dense diets should be formulated to aid calves in recovery, although it may take several days to return stressed calves to positive energy and protein balances. If deficiencies can be compensated for, energy and protein source seem to have minimal impact on health and performance of newly received, stressed calves. However, continued research in the area of nutrient requirements of calves facing immune challenges could prove beneficial in formulating nutritional management plans for stressed calves. This outcome would be especially beneficial for meeting nutrient/ metabolic requirements during an $A P R$, with potential consequences for long-term outcomes.

Disclosure The author has nothing to disclose.

\section{References}

1. Duff GC, Galyean ML. Board-invited review: recent advances in management of highly stressed, newly received feedlot cattle. J Anim Sci 2007;85:823-40.

2. O'Conner AM, Sorden SD, Apley MD. Association between the existence of calves persistently infected with bovine viral diarrhea virus and commingling on pen morbidity in feedlot cattle. Am J Vet Res 2005;66:2130-4.

3. Loneragan GH, Thomson DU, Montgomery DL, et al. Prevalence, outcome, and health consequences associated with persistent infection with bovine viral diarrhea virus in feedlot cattle. J Am Vet Med Assoc 2005;226:595-601.

4. Frazer $D$, Ritchie JSD, Frazer AF. The term "stress" in a veterinary context. Br Vet J 1975;131:653-8.

5. Seyle H. The stress of life. New York: McGraw-Hill Book Company; 1976.

6. McNeill JW, Paschal JC, McNeill MS, et al. Effect of morbidity on performance and profitability of feedlot steers. J Anim Sci 1996;74(Suppl. 1):135.

7. McNeill JW. 1996-97 Texas A \& M Ranch to Rail North/South summary Report. College Station (TX): Texas Agricultural Extension Service, Texas A \& M University; 1997. 
8. McNeill JW. 1997-98 Texas A \& M Ranch to Rail North/South Summary Report. College Station (TX): Texas Agricultural Extension Service, Texas A \& M University; 1998.

9. Montgomery TH, Adams R, Cole MA, et al. Influence of feeder calf management and bovine respiratory disease on carcass traits of beef steers. Proceedings: Western Section. J Anim Sci 1984;35:319-27.

10. Perino LJ. Overview of the bovine respiratory disease complex. Compend Contin Educ Pract Vet 1992;14(Suppl):3.

11. Gardner BA, Dolezal HG, Bryant LK, et al. Health of finishing steers: effects on performance, carcass traits, and meat tenderness. J Anim Sci 1999;77:3168-75.

12. Griffin D, Perino L, Whittum T. Feedlot respiratory disease: cost, value of preventives and intervention. Proceedings, Annual Convention - Am. Assoc. of Bovine Prac., vol. 27, San Antonio, TX. Am. Assoc. Bovine Prac., Rome, GA, July, 1995.

13. Step DL, Krehbiel CR, DePra HA, et al. Effects of commingling beef calves from difference sources and weaning protocols during a forty-two-day receiving period on performance and bovine respiratory disease. J Anim Sci 2008;86: 3146-58.

14. Cole NA. Review of bovine respiratory disease: nutrition and disease interactions. In: Smith R, editor. Review of bovine respiratory disease - Schering-Plough Animal Health. Trenton (NJ): Veterinary Learning Systems; 1996. p. 57-74.

15. Gruys $E$, Toussaint MJM, Niewold TA, et al. Acute phase reaction and acute phase proteins. J Zhejiang Univ Sci 2005;6B:1045-56.

16. Cray C, Zaias J, Altman NH. Acute phase response in animals: a review. Comp Med 2009;59:517-26.

17. Eckersall PD, Bell R. Acute phase proteins: biomarkers of infection and inflammation in veterinary medicine. Vet J 2010;185:23-7.

18. De Maio A, de Lourdes Mooney M, Matesic LE, et al. Acute phase response in calves following infection with Pasteurella haemolytica, Ostertagia ostertagi and endotoxin administration. Res Vet Sci 1989;47:203-7.

19. Selzman $\mathrm{CH}$, Shames BD, Miller SA, et al. Therapeutic implications of interleukin10 in surgical disease. Shock 1998;10:309-18.

20. Peterson HH, Nielsen JP, Heegaard PMH. Application of acute phase protein measurements in veterinary clinical chemistry. Vet Res 2004;35:163-87.

21. Eckersall PD, Conner JG. Bovine and canine acute phase proteins. Vet Res Commun 1988;12:169-78.

22. Saini PK, Raiz M, Webert DW, et al. Development of a simple enzyme immunoassay for blood haptoglobin concentration in cattle and its application in improving food safety. Am J Vet Res 1998;59:1101-7.

23. Baumann H, Gauldie J. The acute phase response. Immunol Today 1994;15: 74-80.

24. Cooke RF, Bohnert DW. Technical note: bovine acute-phase response after corticotrophin-release hormone challenge. J Anim Sci 2011;89:252-7. 
25. Christ B, Nath A, Heinrich PC. Inhibition by recombinant human interleukin- 6 of the glucagon-dependent induction of phosphoenolpyruvate carboxykinase and of the insulin-dependent induction of glucokinase gene expression in culture rat hepatocytes: regulation of gene transcription and messenger RNA degradation. Hepatology 1994;20:1577-83.

26. Berry BA, Confer AW, Krehbiel CR, et al. Effects of dietary energy and starch concentrations for newly received feedlot calves: II. Acute-phase protein response. J Anim Sci 2004;82:845-50.

27. Burciaga-Robles LO, Step DL, Krehbiel CR, et al. Effects of exposure to calves persistently infected with bovine viral diarrhea virus type $1 \mathrm{~b}$ and subsequent infection with Mannheima haemolytica on clinical signs and immune parameters: Model for bovine respiratory disease via viral and bacterial interaction. J Anim Sci 2010;88:2166-78.

28. Qiu X, Arthington JD, Riley DG, et al. Genetic effects on acute phase protein response to the stresses of weaning and transportation in beef calves. J Anim Sci 2007;85:2367-74.

29. Cooke RF, Arthington JD, Austin BR, et al. Effects of acclimation to handling on performance, reproductive, and physiological responses of Brahman-crossbred heifers. J Anim Sci 2009;87:3403-12.

30. Horadagoda NU, Knox KMG, Gibbs HA, et al. Acute phase proteins in cattle: discrimination between acute and chronic inflammation. Vet Rec 1999;144: 437-41.

31. Nikunen $\mathrm{S}$, Härtel $\mathrm{H}$, Orro $\mathrm{T}$, et al. Association of bovine respiratory disease with clinical status and acute phase proteins in calves. Comp Immun Micro Inf Dis 2007;30:143-51.

32. Waggoner JW, Löest CA, Mathis CP, et al. Effects of rumen-protected methionine supplementation and bacterial lipopolysaccharide infusion on nitrogen metabolism and hormonal responses of growing beef steers. J Anim Sci 2009;87: 681-92.

33. Reeds PJ, Fjeld CR, Jahoor F. Do the differences between the amino acid compositions of acute-phase and muscle proteins have a bearing on nitrogen loss in traumatic states? J Nutr 1994;124:906-10.

34. Jackson KS, Carstens GE, Tedeschi LO, et al. Changes in feeding behavior patterns and dry matter intake before clinical symptoms associated with bovine respiratory disease in growing bulls. J Anim Sci 2016;94:1644-52.

35. Wolfger B, Schwartzkopf-Genswein KS, Barkema HW, et al. Feeding behavior as an early predictor of bovine respiratory disease in North American feedlot systems. J Anim Sci 2015;93:377-85.

36. Hutcheson DP, Cole NA. Management of transit-stress syndrome in cattle: nutritional and environmental effects. J Anim Sci 1986;62:555-60.

37. Galyean ML, Hubbert ME. Effects of season, health, and management on feed intake by beef cattle. In: Symposium: Intake by Feedlot Cattle. Okla. Agric. Exp. Sta. P-942. Pages 226-234. Oklahoma State Univ., Stillwater, September 11-13, 1995. 
38. Sowell BF, Branine ME, Bowman JGP, et al. Feeding and watering behavior of healthy and morbid steers in a commercial feedlot. J Anim Sci 1999;77:1105-12.

39. National Academies of Sciences, Engineering, Medicine (NASEM). Nutrient requirements of beef cattle. 8th rev edition. Washington, DC: The National Academies Press; 2016. https://doi.org/10.17226/19014

40. Montgomery SP, Sindt JJ, Greenquist MA, et al. Plasma metabolites of receiving heifers and the relationship between apparent bovine respiratory disease, body weight gain, and carcass characteristics. J Anim Sci 2009;87:328-33.

41. McBeth LJ, Gill DR, Krehbiel CR, et al. Effect of health status during the receiving period on subsequent feedlot performance and carcass characteristics. Okla Agric Exp Sta Res Rep 2001;986:30-3.

42. Holland BP, Burciaga-Robles LO, VanOverbeke DL, et al. Effect of bovine respiratory disease during preconditioning on subsequent feedlot performance, carcass characteristics, and beef attributes. J Anim Sci 2010;88:2486-99.

43. Wilson BK, Step DL, Maxwell CL, et al. Effect of bovine respiratory disease during the receiving period on steer finishing performance, efficiency, carcass characteristics, and lung scores. Prof Anim Sci 2017;33:24-36.

44. Nockels CF. The role of vitamins in modulating disease resistance. Vet Clin North Am Food Anim Pract 1988;4:531-42.

45. Lofgreen GP. Nutrition and management of stressed beef calves. In: Radostits OM, editor. Veterinary Clinics of North America: large animal practice, vol. 5. Philadelphia: W. B. Saunders; 1983. p. 87-101. No. 1.

46. Lofgreen GP. Nutrition and management of stressed beef calves: an update. In: Howard JL, editor. Veterinary Clinics of North America: food animal practice, vol. 4. Philadelphia: W. B. Saunders; 1988. p. 509-22. No. 3.

47. Lofgreen GP, Dunbar JR, Addis DG, et al. Energy level in starting rations for calves subjected to marketing and shipping stress. J Anim Sci 1975;41:1256-65.

48. Fluharty FL, Loerch SC. Effects of dietary energy source and level on performance of newly arrived feedlot calves. J Anim Sci 1996;74:504-13.

49. Pritchard $\mathrm{RH}$, Mendez JK. Effects of preconditioning on pre- and post-shipment performance of feeder calves. J Anim Sci 1990;68:28-34.

50. Berry BA, Krehbiel CR, Confer AW, et al. Effects of dietary energy and starch concentrations for newly received feedlot calves: I. Growth performance and health. J Anim Sci 2004;82:837-44.

51. Rivera JD, Duff GC, Galyean ML, et al. Effects of graded levels of vitamin E on inflammatory response and evaluation of methods of delivering supplemental vitamin E on performance and health of beef steers. Prof Anim Sci 2003;19: $171-7$.

52. Spore TJ, Montgomery SP, Titgemeyer EC, et al. Effects of a high-energy programmed feeding protocol on nutrient digestibility, health, and performance of newly received growing beef cattle. Appl Anim Sci 2019;35:397-407.

53. Galyean ML. Protein levels in beef cattle finishing diets: industry application, university research, and systems results. J Anim Sci 1996;74:2860-70.

54. Galyean ML, Gunter SA, Malcolm-Callis KJ, et al. Effects of crude protein 
concentration in the receiving diet on performance and health of newly received beef calves. Clayton Livestock Res Ctr Prog Rep 1993. No. 88. N.M. Agric. Exp. Sta., Las Cruces.

55. Fluharty FL, Loerch SC. Effects of protein concentration and protein source on performance of newly arrived feedlot steers. J Anim Sci 1995;73:1585-94.

56. Galyean ML, Perino LJ, Duff GC. Interaction of cattle health/immunity and nutrition. J Anim Sci 1999;77:1120-34.

57. Cole NA. Receiving nutrition and management for feedlots. Proc. XXV American Association of Bovine Practitioners Conference. St. Paul, MN, Aug 31-Sept 4, 1992. 2. p. 309-314. 1992.

58. Pritchard RH, Boggs DL. Use of DDGS as the primary source of supplemental crude protein in calf receiving diets. 2006 South Dakota Beef Report; 2006. p. 6-9.

59. Van Koevering MT, Gill DR, Owens FN. The effects of escape protein on health and performance of shipping stressed calves. Oklahoma State Univ. Anim Sci Res 1991;134:156-62.

60. Garcia ME, Oosthuysen E, Graves JR, et al. Effects of level and source of supplemental trace minerals on growth responses of beef calves received from New Mexico ranches. Proc West Sect Am Soc Anim Sci 2014;65:91-4.

61. Ryan AW, Kegley EB, Hawley J, et al. Supplemental trace minerals (zinc, copper, and manganese) as sulfates, organic amino acid complexes, or hydroxy trace mineral sources for shipping stressed calves. Prof Anim Sci 2015;31:333-41.

62. Goodall SR, Schuetze CJ. Complexed versus amino acid-chelated trace mineral programs in high-risk calves during receiving. Transl Anim Sci 2019;3:1636-40.

63. Roberts SL, May ND, Brauer $C L$, et al. Effect of injectable trace mineral administration on health, performance, and vaccine response of newly received feedlot cattle. Prof Anim Sci 2016;32:842-8.

64. Chang X, Mowat DN. Supplemental chromium for stressed and growing feeder calves. J Anim Sci 1992;70:559-65.

65. Moonsie-Shageer S, Mowat DN. Effect of level of supplemental chromium on performance, serum constituents, and immune response of stressed feeder steer calves. J Anim Sci 1993;71:232-8.

66. Bernhard BC, Burdick NC, Rounds W, et al. Chromium supplementation alters the performance and health of feedlot cattle during the receiving period and enhances their metabolic response to a lipopolysaccharide (LPS) challenge. J Anim Sci 2012;90:3879-88.

67. Elam NA. Impact of vitamin E supplementation on newly received calves. Proc. Colorado Nutr. Ft. Collins (CO): Roundtable, Colorado State Univ.; 2006. 